\title{
Editorial
}

\section{Approach of Serial Crystallography II}

\author{
Ki-Hyun Nam (1)
}

check for updates

Citation: Nam, K.-H. Approach of Serial Crystallography II. Crystals 2021, 11, 655. https://doi.org/ $10.3390 /$ cryst11060655

Received: 5 June 2021

Accepted: 8 June 2021

Published: 9 June 2021

Publisher's Note: MDPI stays neutral with regard to jurisdictional claims in published maps and institutional affiliations.

Copyright: (c) 2021 by the author. Licensee MDPI, Basel, Switzerland. This article is an open access article distributed under the terms and conditions of the Creative Commons Attribution (CC BY) license (https:// creativecommons.org/licenses/by/ $4.0 /)$.
Department of Life Science, Pohang University of Science and Technology, Pohang 37673, Gyeongbuk, Korea; structures@postech.ac.kr

\begin{abstract}
Serial crystallography (SX) is an emerging X-ray crystallographic method for determining macromolecule structures. It can address concerns regarding the limitations of data collected by conventional crystallography techniques, which require cryogenic-temperature environments and allow crystals to accumulate radiation damage. Time-resolved SX studies using the pump-probe methodology provide useful information for understanding macromolecular mechanisms and structure fluctuation dynamics. This Special Issue deals with the serial crystallography approach using an X-ray free electron laser (XFEL) and synchrotron X-ray source, and reviews recent SX research involving synchrotron use. These reports provide insights into future serial crystallography research trends and approaches.
\end{abstract}

Serial crystallography (SX) experiments using an X-ray free electron laser (XFEL) with a short pulse width, or short time $X$-ray $(<100 \mathrm{~ms})$ exposure in a synchrotron, minimize radiation damage to crystals compared with traditional X-ray crystallographic methods [1,2]. Moreover, SX data collection at room temperature provides more biologically reliable data on structural dynamics in macromolecules compared to cryo-crystallographic techniques [3-5]. In addition, in SX data collection, if a crystal sample is stimulated with a pump, such as an optical laser or a ligand/inhibitor solution, and then diffraction data are collected by exposure to X-rays after a selected time delay. This can time-resolve molecular mechanisms of macromolecules [6,7]. Thus, SX techniques provide more biologically reliable structural information than conventional $X$-ray crystallography and can provide detailed information on their mechanisms of action.

Each XFEL facility or synchrotron capable of performing SX can provide unique X-ray characteristics (photon flux, $X$-ray size, repetition rate, jitter, etc.) and different experimental environments (vacuum, helium or ambient, temperature, etc.), as well as a diverse array of preferred sample delivery techniques (injection, fixed-target scanning, hybrid methods, etc.) [8]. Accordingly, SX experimental approaches will be diverse, and they will depend on the facility, target samples, and desired information [5,8,9]. In this Special Issue, we discuss approaches to serial crystallography. Specifically, we cover two SX research articles and one review, as follows:

Gorel et al. reported shock damage analysis in serial femtosecond crystallography data collected at MHz XFEL [10]. When the MHz XFEL beam penetrates the liquid jet, supersonic shock waves are generated at the XFEL transmission point. The effect of these shock waves on the next crystal sample was investigated. The results of these investigations confirm that there was no damage to the crystal sample due to the characteristics of the XFEL used. This approach provides data acquisition efficiency in SFX experiments with $\mathrm{MHz}$ XFEL pulses. In addition, it is useful for verifying the reliability of data collected when a supersonic shock wave is generated.

Park et al. reported fixed-target serial synchrotron crystallography using a nylon mesh and an enclosed film-based sample holder [11]. This sample delivery method was derived from a previously developed fixed-target sample delivery method applied in serial femtosecond crystallography (SFX) studies [12], but the sample holder was re-designed to be suitable for a beamline instrument at a synchrotron, and this method was used to 
determine the crystal structures of model samples while changing exposure time and oscillation parameters. This approach can be applied in existing macromolecular beamline instruments without the installation of a special device.

Martin-Garcia provided a timely review of the recent time-resolved SX studies conducted in synchrotrons [13]. In their review, the importance of time-resolved SX is summarized comprehensively as the target samples and data collection environments of 41 successful SSX studies are discussed. Furthermore, notable sample delivery methods, including viscous jets, the hit-and-return (HARE) system, the liquid application method for time-resolved analysis (LAMA) system, the mix-and-diffusion device, and microfluidics devices have been covered.

During the drafting of this Special Issue, various SX technologies have continued to further develop. Although these studies are not addressed in this Special Issue, they provide useful information for maintaining an optimal environment specific to each facility [14-19] or target sample delivery method [20-35]. All articles in this Special Issue discussing SX approaches and recently developed $S X$ techniques will provide great opportunities to better understand macromolecular functions in greater depth.

I would like to thank all authors for providing excellent manuscripts, the reviewers for providing constructive feedback, and the editors of Crystals for working together on this Special Issue.

Funding: This work was funded by the National Research Foundation of Korea (NRF-2017M3A9F602 9736).

Institutional Review Board Statement: Not applicable.

Informed Consent Statement: Not applicable.

Data Availability Statement: Not applicable.

Conflicts of Interest: The author declares no conflict of interest.

\section{References}

1. Standfuss, J.; Spence, J. Serial crystallography at synchrotrons and X-ray lasers. IUCrJ 2017, 4, 100-101. [CrossRef] [PubMed]

2. Martin-Garcia, J.M.; Conrad, C.E.; Coe, J.; Roy-Chowdhury, S.; Fromme, P. Serial femtosecond crystallography: A revolution in structural biology. Arch. Biochem. Biophys. 2016, 602, 32-47. [CrossRef] [PubMed]

3. Weinert, T.; Olieric, N.; Cheng, R.; Brunle, S.; James, D.; Ozerov, D.; Gashi, D.; Vera, L.; Marsh, M.; Jaeger, K.; et al. Serial millisecond crystallography for routine room-temperature structure determination at synchrotrons. Nat. Commun. 2017, 8, 542. [CrossRef]

4. Nam, K.H. Room-Temperature Structure of Xylitol-Bound Glucose Isomerase by Serial Crystallography: Xylitol Binding in the M1 Site Induces Release of Metal Bound in the M2 Site. Int. J. Mol. Sci. 2021, 22, 3892. [CrossRef] [PubMed]

5. Nam, K.H. Sample Delivery Media for Serial Crystallography. Int. J. Mol. Sci. 2019, 20, 1094. [CrossRef] [PubMed]

6. Schmidt, M. Time-Resolved Macromolecular Crystallography at Pulsed X-ray Sources. Int. J. Mol. Sci. 2019, 20, 1401. [CrossRef] [PubMed]

7. Schmidt, M. Reaction Initiation in Enzyme Crystals by Diffusion of Substrate. Crystals 2020, 10, 116. [CrossRef]

8. Nam, K.H. Approach of Serial Crystallography. Crystals 2020, 10, 854. [CrossRef]

9. Cheng, R. Towards an Optimal Sample Delivery Method for Serial Crystallography at XFEL. Crystals 2020, 10, 215. [CrossRef]

10. Gorel, A.; Grünbein, M.; Bean, R.; Bielecki, J.; Hilpert, M.; Cascella, M.; Colletier, J.-P.; Fangohr, H.; Foucar, L.; Hartmann, E.; et al. Shock Damage Analysis in Serial Femtosecond Crystallography Data Collected at MHz X-ray Free-Electron Lasers. Crystals 2020, 10, 1145. [CrossRef]

11. Park, S.-Y.; Choi, H.; Eo, C.; Cho, Y.; Nam, K.H. Fixed-Target Serial Synchrotron Crystallography Using Nylon Mesh and Enclosed Film-Based Sample Holder. Crystals 2020, 10, 803. [CrossRef]

12. Lee, D.; Baek, S.; Park, J.; Lee, K.; Kim, J.; Lee, S.J.; Chung, W.K.; Lee, J.L.; Cho, Y.; Nam, K.H. Nylon mesh-based sample holder for fixed-target serial femtosecond crystallography. Sci. Rep. 2019, 9, 6971. [CrossRef]

13. Martin-Garcia, J.M. Protein Dynamics and Time Resolved Protein Crystallography at Synchrotron Radiation Sources: Past, Present and Future. Crystals 2021, 11, 521. [CrossRef]

14. Ren, Z.; Wang, C.; Shin, H.; Bandara, S.; Kumarapperuma, I.; Ren, M.Y.; Kang, W.; Yang, X. An automated platform for in situ serial crystallography at room temperature. IUCrJ 2020, 7, 1009-1018. [CrossRef] 
15. Shilova, A.; Lebrette, H.; Aurelius, O.; Nan, J.; Welin, M.; Kovacic, R.; Ghosh, S.; Safari, C.; Friel, R.J.; Milas, M.; et al. Current status and future opportunities for serial crystallography at MAX IV Laboratory. J. Synchrotron Radiat. 2020, 27, 1095-1102. [CrossRef]

16. Ursby, T.; Åhnberg, K.; Appio, R.; Aurelius, O.; Barczyk, A.; Bartalesi, A.; Bjelčić, M.; Bolmsten, F.; Cerenius, Y.; Doak, R.B.; et al. BioMAX-The first macromolecular crystallography beamline at MAX IV Laboratory. J. Synchrotron Radiat. 2020, 27, 1415-1429. [CrossRef]

17. Han, H.; Round, E.; Schubert, R.; Gül, Y.; Makroczyová, J.; Meza, D.; Heuser, P.; Aepfelbacher, M.; Barák, I.; Betzel, C.; et al. The XBI BioLab for life science experiments at the European XFEL. J. Appl. Crystallogr. 2021, 54, 7-21. [CrossRef]

18. Schneider, D.K.; Shi, W.; Andi, B.; Jakoncic, J.; Gao, Y.; Bhogadi, D.K.; Myers, S.F.; Martins, B.; Skinner, J.M.; Aishima, J.; et al. FMX-The Frontier Microfocusing Macromolecular Crystallography Beamline at the National Synchrotron Light Source II. J. Synchrotron Radiat. 2021, 28, 650-665. [CrossRef] [PubMed]

19. Hasegawa, K.; Baba, S.; Kawamura, T.; Yamamoto, M.; Kumasaka, T. Evaluation of the data-collection strategy for roomtemperature micro-crystallography studied by serial synchrotron rotation crystallography combined with the humid air and glue-coating method. Acta Crystallogr. D Biol. Crystallogr. 2021, 77, 300-312. [CrossRef]

20. Berntsen, P.; Sharma, R.; Kusel, M.; Abbey, B.; Darmanin, C. Lipidico Injection Protocol for Serial Crystallography Measurements at the Australian Synchrotron. J. Vis. Exp. 2020. [CrossRef] [PubMed]

21. Zhao, F.-Z.; Sun, B.; Yu, L.; Xiao, Q.-J.; Wang, Z.-J.; Chen, L.-L.; Liang, H.; Wang, Q.-S.; He, J.-H.; Yin, D.-C. A novel sample delivery system based on circular motion for in situ serial synchrotron crystallography. Lab Chip 2020, 20, 3888-3898. [CrossRef] [PubMed]

22. Calvey, G.D.; Katz, A.M.; Zielinski, K.A.; Dzikovski, B.; Pollack, L. Characterizing Enzyme Reactions in Microcrystals for Effective Mix-and-Inject Experiments using X-ray Free-Electron Lasers. Anal. Chem. 2020, 92, 13864-13870. [CrossRef]

23. Rabe, P.; Beale, J.H.; Butryn, A.; Aller, P.; Dirr, A.; Lang, P.A.; Axford, D.N.; Carr, S.B.; Leissing, T.M.; McDonough, M.A.; et al. Anaerobic fixed-target serial crystallography. IUCrJ 2020, 7, 901-912. [CrossRef] [PubMed]

24. Echelmeier, A.; Cruz Villarreal, J.; Messerschmidt, M.; Kim, D.; Coe, J.D.; Thifault, D.; Botha, S.; Egatz-Gomez, A.; Gandhi, S.; Brehm, G.; et al. Segmented flow generator for serial crystallography at the European X-ray free electron laser. Nat. Commun. 2020, 11. [CrossRef]

25. Vakili, M.; Vasireddi, R.; Gwozdz, P.V.; Monteiro, D.C.F.; Heymann, M.; Blick, R.H.; Trebbin, M. Microfluidic polyimide gas dynamic virtual nozzles for serial crystallography. Rev. Sci. Instrum. 2020, 91. [CrossRef] [PubMed]

26. Nam, K.H. Lard Injection Matrix for Serial Crystallography. Int. J. Mol. Sci. 2020, 21, 5977. [CrossRef] [PubMed]

27. Huang, C.-Y.; Meier, N.; Caffrey, M.; Wang, M.; Olieric, V. 3D-printed holders for in meso in situ fixed-target serial X-ray crystallography. J. Appl. Crystallogr. 2020, 53, 854-859. [CrossRef]

28. Lee, K.; Lee, D.; Baek, S.; Park, J.; Lee, S.J.; Park, S.; Chung, W.K.; Lee, J.-L.; Cho, H.-S.; Cho, Y.; et al. Viscous-medium-based crystal support in a sample holder for fixed-target serial femtosecond crystallography. J. Appl. Crystallogr. 2020, 53, 1051-1059. [CrossRef]

29. Nam, K.H. Polysaccharide-Based Injection Matrix for Serial Crystallography. Int. J. Mol. Sci. 2020, 21, 3332. [CrossRef]

30. Monteiro, D.C.F.; Von Stetten, D.; Stohrer, C.; Sans, M.; Pearson, A.R.; Santoni, G.; Van der Linden, P.; Trebbin, M. 3D-MiXD: 3D-printed X-ray-compatible microfluidic devices for rapid, low-consumption serial synchrotron crystallography data collection in flow. IUCrJ 2020, 7, 207-219. [CrossRef]

31. Sugahara, M.; Motomura, K.; Suzuki, M.; Masuda, T.; Joti, Y.; Numata, K.; Tono, K.; Yabashi, M.; Ishikawa, T. Viscosity-adjustable grease matrices for serial nanocrystallography. Sci. Rep. 2020, 10, 1371. [CrossRef] [PubMed]

32. Shelby, M.L.; Gilbile, D.; Grant, T.D.; Seuring, C.; Segelke, B.W.; He, W.; Evans, A.C.; Pakendorf, T.; Fischer, P.; Hunter, M.S.; et al. A fixed-target platform for serial femtosecond crystallography in a hydrated environment. IUCrJ 2020, 7, 30-41. [CrossRef] [PubMed]

33. Nam, K.H. Shortening injection matrix for serial crystallography. Sci. Rep. 2020, 10, 107. [CrossRef] [PubMed]

34. Šarler, B.; Zahoor, R.; Bajt, S. Alternative Geometric Arrangements of the Nozzle Outlet Orifice for Liquid Micro-Jet Focusing in Gas Dynamic Virtual Nozzles. Materials 2021, 14, 1572. [CrossRef] [PubMed]

35. Nam, K.H. Stable sample delivery in viscous media via a capillary for serial crystallography. J. Appl. Crystallogr. 2020, 53, 45-50. [CrossRef] 